\title{
Length-Weight Relationships for Eight Caught Marine Fish Using Midwater Trawler in Chabahar Fishing Grounds, Sistan and Bluchestan (The Sea of Oman)
}

\author{
Ali Sepahi, Saeed Gorgin and Mojtaba Pouladi* \\ Department of Fisheries, Gorgan University of Agricultural Sciences and Natural Resources, Iran
}

Submission: September 10, 2019; Published: October 21, 2019

Corresponding author: Mojtaba Pouladi, Department of Fisheries, Faculty of Fisheries and Environment Sciences, Gorgan University of Agricultural Sciences and Natural Resources, Gorgan, Golestan, Iran

\begin{abstract}
The present research provides length-weight relationship (LWR) of eight fish species included Pomadasys stridens (Forsskål, 1775), Epinephelus areolatus (Forsskål, 1775), Pristipomoides multidens (Day, 1871), Pomadasys maculatus (Bloch, 1793), Johnius borneensis (Bleeker, 1851), Diagrmma pictum (Thunberg, 1792), Epinephelus malabaricus (Bloch \& Schneider, 1801) and Epinephelus coioides (Hamilton, 1822) from Chabahr fishing grounds (latitude $25^{\circ} 11^{\prime}$ to $25^{\circ} 12^{\prime} \mathrm{N}$; longitude $60^{\circ} 04^{\prime}$ to $60^{\circ} 13^{\prime} \mathrm{E}$ ) in the Sea of Oman. All fish specimens were caught using midwater trawl net, with $65 \mathrm{~mm}$ mesh size in the cod-end, from April to May 2016 during the spring season. The LWRs for fish species were $\mathrm{W}=$ $0.0127 \mathrm{~L}^{2.874}$ for $P$. stridens, $\mathrm{W}=0.0153 \mathrm{~L}^{2.971}$ for E. areolatus, $\mathrm{W}=0.0227 \mathrm{~L}^{2.873}$ for $P$. multidens, $\mathrm{W}=0.0534 \mathrm{~L}^{2.689}$ for $P$. maculatus, $\mathrm{W}=0.0023 \mathrm{~L}^{3.157}$ for J. borneensis, $\mathrm{W}=0.0164 \mathrm{~L}^{2.807}$ for D. pictum, $\mathrm{W}=0.0487 \mathrm{~L}^{3.287}$ for E. malabaricus, and $\mathrm{W}=0.0487 \mathrm{~L}^{3.287}$ for E. coioides, respectively.
\end{abstract}

Keywords: Marine fish; Fishing grounds; Chabahr fishing; Bluchestan province

\section{Introduction}

Length-weight relationships are fundamental information to understanding the biological parameters of fishes for fisheries management, fish stock assessment, determination of biomass using measured weights, comparison of life cycle characteristic of fish populations from different regions, and estimation of weight ranges from length ranges [1-4]. This research prepares length-weight relationships for eight fish species in Chabahr fishing grounds located in the Sea of Oman.

\section{Materials and Methods}

This study was conducted between April and May 2016 from Chabahar fishing grounds, Sistan and Bluchestan province (latitude $25^{\circ} 11^{\prime}$ to $25^{\circ} 12^{\prime} \mathrm{N}$; longitude $60^{\circ} 04^{\prime}$ to $60^{\circ} 13^{\prime} \mathrm{E}$ ) (latitude $25^{\circ} 11^{\prime}$ to $25^{\circ} 12^{\prime} \mathrm{N}$; longitude $60^{\circ} 04^{\prime}$ to $60^{\circ} 13^{\prime} \mathrm{E}$ ) of the trapped species are shown in Table 1.
Table 1: Length-weight relationship parameters for eight marine fish in the Chabahr fishing ground, Sistan and Bluchestan, the Sea of Oman 2016.

\begin{tabular}{|c|c|c|c|c|c|c|c|c|}
\hline \multirow{2}{*}{ Species } & \multirow{2}{*}{$\mathbf{n}$} & \multicolumn{2}{|c|}{ Length $\mathbf{( c m )}$} & \multicolumn{5}{c|}{ LWR parameters and statistics } \\
\cline { 6 - 11 } & & Min & Max & $\mathbf{a}$ & a CI 95\% & b & b CI 95\% & $\mathbf{r}^{\mathbf{2}}$ \\
\hline Pomadasys stridens (Forsskål, 1775) & 62 & 7.5 & 14.6 & 0.0127 & $0.0103-0.0157$ & 2.845 & $2.526-3.182$ & 0.966 \\
\hline Epinephelus areolatus (Forsskål, 1775) & 76 & 16.2 & 45.6 & 0.0153 & $0.0128-0.0175$ & 2.971 & $2.688-3.240$ & 0.98 \\
\hline Pristipomoides multidens (Day, 1871) & 84 & 19.5 & 54.2 & 0.0227 & $0.0195-0.0268$ & 2.873 & $2.599-3.208$ & 0.984 \\
\hline Pomadasys maculatus (Bloch, 1793) & 75 & 34.7 & 58.4 & 0.0534 & $0.0489-0.0645$ & 2.689 & $2.445-2.948$ & 0.973 \\
\hline Johnius borneensis (Bleeker, 1851) & 55 & 17.5 & 32.5 & 0.0023 & $0.0018-0.0027$ & 3.157 & $2.823-3.475$ & 0.968 \\
\hline
\end{tabular}

in the Sea of Oman. The fish specimens were collected using midwater trawler with $65 \mathrm{~mm}$ (STR) mesh size in the coded. Trawl duration varied from 2 to 3 hours at speeds of about 2.5 to 3 knots. For each fish specimen, the total length (TL) was measured with a digital caliper to the nearest $0.1 \mathrm{~mm}$, and body weight was measured on a digital scale to $0.01 \mathrm{~g}$. LWRs were estimated by linear equation $[5,6]$ : . Where $\mathrm{W}$ is the whole-body weight $(\mathrm{g}$ ) and $\mathrm{L}$ the total length $(\mathrm{cm})$. Log-log plots of the lengthweight pairs were performed to identify outliers. The optimum regression parameters were fitted by minimizing the residuals errors by the least square residuals method $[7,8]$.

\section{Results}

Totally, 679 specimens were collected. LWRs characteristics 


\begin{tabular}{|c|c|c|c|c|c|c|c|c|}
\hline Diagrmma pictum (Thunberg, 1792) & 106 & 37.5 & 89.1 & 0.0164 & $0.0139-0.0188$ & 2.807 & $2.431-3.204$ & 0.977 \\
\hline Epinephelusmalabaricus (Bloch\&Schneider,1801) & 128 & 28.6 & 95.8 & 0.0487 & $0.0446-0.0524$ & 3.287 & $2.902-3.578$ & 0.992 \\
\hline Epinephelus coioides (Hamilton, 1822) & 93 & 23.1 & 94.5 & 0.0389 & $0.0334-0.0435$ & 3.169 & $2.725-3.371$ & 0.98 \\
\hline
\end{tabular}

$\mathrm{N}=$ sample size; Min = minimum; Max = maximum; $\mathrm{a}=$ intercept of log-log relationship; $\mathrm{b}=$ slope of relationship; CI 95\% = confidence limits $r^{2}=$ coefficient of determination

\section{Discussion}

Length-weight relationships in different fish species are affected by numerous factors such as gonad maturity stage, temperature, reproductive activities, food availability, gender, population dynamics, season, environment desirability, health conditions, fishing gears, sample size and preservation methods $[9,10]$. Based on Froese (2006) the proper ranges of $b$ value are between 2.5 and 3.5 which the LWR slopes for eight collected species were within the estimated ranges. Nevertheless, these obtained results are valuable for fishery and biology researchers for interrelated studies and protection of fish stocks in the Sea of Oman in the next years [11]

\section{Acknowledgment}

The authors are thankful to Vice Presidency for Research and Technology of Gorgan University of Agricultural Sciences and Natural Resources (GAU) for their supports during study period.

\section{References}

1. Morato T, P Afonso, P Lourinho, JP Barreiros, RS Santos, et al. (2001) Length-weight relationships for 21 coastal fish species of the Azores, north-eastern Atlantic. Fisheries Research 50(3): 297-302.

2. Human B A, Al-Busaidi H (2008) Length and Weight Relationships for 31 Species of Fishes Caught by Trawl Off the Arabian Sea Coast of Oman. Journal of Agricultural and Marine Sciences 13: 43-52.

3. Radkhah A, Eagderi S (2015) Length-weight and length-length relationships and condition factor of six cyprinid fish species of Zarrineh River (Urmia Lake basin, Iran). Iranian Journal of Ichthyology 2(1): 6164.

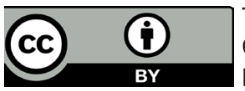

is work is licensed under Creative

Commons Attribution 4.0 Licens

DOI: 10.19080/OFOAJ.2019.10.555801
4. Saberi M, Paighambari S Y, Darvishi M, Farkhondeh Shilsar G (2017) Length-weight relationships of six fish species from the Coastal Waters of Jask, Iran. Journal of Applied Ichthyology, 33(6), 1226-1228.

5. Froese R, Tsikliras A C, Stergiou K I (2011) Editorial note on weightlength relations of fishes. Acta Ichthyologica et Piscatoria, 30(10): 261263.

6. Froese R (2006) Cube law, condition factor and weight-length relationships: history, meta-analysis and recommendations. Journal of Applied Ichthyology 22(4): 241-253.

7. Haddon M (2011) Modelling and quantitative methods in fisheries. In: ( $2^{\text {nd }}$ edn). CRC Press, Taylor \& Francis Group, New York, Pp 449.

8. Hasankhani M, Keivany Y, Daliri M, Pouladi M, Soofiani N M (2013) Length-weight and length-length relationships of four species Barbus lacerta (Heckel, 1843), Oxynoemacheilus angorae (Steindachner 1897), Squalius lepidus (Heckel, 1843) and Pseudorasbora parva (Temminck \& Schlegel, 1846) from the Sirwan River (western Iran). Journal of Applied Ichthyology, 30(1): 206-207.

9. Stergiou K, Moutopoulos D (2001) A review of length-weight relationships of fishes from Greek marine waters. Naga, the ICLARM Quarterly 24(1-2): 23-39.

10. Salahi-gezaz M, Paighambari S Y, Abbaspour-Naderi R, Vesaghi M J (2015) Length-weight relationships for two marine fish species from the Gulf of Oman: Uranoscopus guttatus (Cuvier, 1829) and Lagocephalus inermis (Temminck \& Schlegel, 1850). Journal of Applied Ichthyology 31(6): 1142-1143.

11. Parsa M, Rahnama B, Mahmoudi Khoshdarehgi M (2017) Lengthweight relationships of five fish species from Carangidae family in waters of the northern Persian Gulf, Iran. Journal of Applied Ichthyology 33(5): 1055-1057.

\section{Your next submission with Juniper Publishers will reach you the below assets}

- Quality Editorial service

- Swift Peer Review

- Reprints availability

- E-prints Service

- Manuscript Podcast for convenient understanding

- Global attainment for your research

- Manuscript accessibility in different formats

( Pdf, E-pub, Full Text, Audio)

- Unceasing customer service

Track the below URL for one-step submission

https://juniperpublishers.com/online-submission.php 